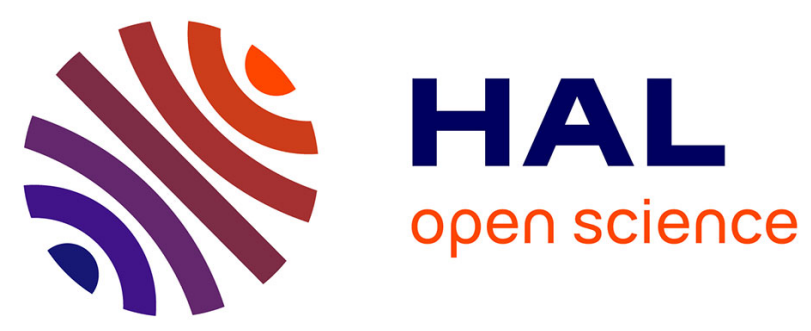

\title{
Contribution of peatland permafrost to dissolved organic matter along a thaw gradient in North Siberia
}

L. Gandois, Alison May Hoyt, Christine Hatté, Laurent Jeanneau, Roman

Teisserenc, Marine Liotaud, Nikita Tananaev

\section{- To cite this version:}

L. Gandois, Alison May Hoyt, Christine Hatté, Laurent Jeanneau, Roman Teisserenc, et al.. Contribution of peatland permafrost to dissolved organic matter along a thaw gradient in North Siberia. Environmental Science and Technology, 2019, 53 (24), pp.14165-14174. 10.1021/acs.est.9b03735 . insu-02358892

\section{HAL Id: insu-02358892 \\ https://hal-insu.archives-ouvertes.fr/insu-02358892}

Submitted on 12 Nov 2019

HAL is a multi-disciplinary open access archive for the deposit and dissemination of scientific research documents, whether they are published or not. The documents may come from teaching and research institutions in France or abroad, or from public or private research centers.
L'archive ouverte pluridisciplinaire HAL, est destinée au dépôt et à la diffusion de documents scientifiques de niveau recherche, publiés ou non, émanant des établissements d'enseignement et de recherche français ou étrangers, des laboratoires publics ou privés. 
Contribution of peatland permafrost to dissolved organic matter along a thaw gradient in North Siberia

Laure Gandois, Alison May Hoyt, Christine Hatté, Laurent Jeanneau, Roman Teisserenc, Marine Liotaud, and Nikita Tananaev

Environ. Sci. Technol., Just Accepted Manuscript • DOI: 10.1021/acs.est.9b03735 • Publication Date (Web): 11 Nov 2019

Downloaded from pubs.acs.org on November 12, 2019

\section{Just Accepted}

"Just Accepted" manuscripts have been peer-reviewed and accepted for publication. They are posted online prior to technical editing, formatting for publication and author proofing. The American Chemical Society provides "Just Accepted" as a service to the research community to expedite the dissemination of scientific material as soon as possible after acceptance. "Just Accepted" manuscripts appear in full in PDF format accompanied by an HTML abstract. "Just Accepted" manuscripts have been fully peer reviewed, but should not be considered the official version of record. They are citable by the Digital Object Identifier (DOI®). "Just Accepted" is an optional service offered to authors. Therefore, the "Just Accepted" Web site may not include all articles that will be published in the journal. After a manuscript is technically edited and formatted, it will be removed from the "Just Accepted" Web site and published as an ASAP article. Note that technical editing may introduce minor changes to the manuscript text and/or graphics which could affect content, and all legal disclaimers and ethical guidelines that apply to the journal pertain. ACS cannot be held responsible for errors or consequences arising from the use of information contained in these "Just Accepted" manuscripts. 


\section{Contribution of peatland permafrost to dissolved}

\section{2 organic matter along a thaw gradient in North}

\section{Siberia}

\section{Laure Gandois ${ }^{1 *}$, Alison May Hoyt ${ }^{2,3}$, Christine Hatté ${ }^{4}$, Laurent Jeanneau ${ }^{5}$, Roman Teisserenc ${ }^{1}$,} Marine Liotaud ${ }^{5}$, Nikita Tananaev ${ }^{6}$

${ }^{1}$ EcoLab, Université de Toulouse, CNRS, INPT, UPS, Toulouse, France

${ }^{2}$ Max Planck Institute for Biogeochemistry, Hans-Knöll-Straße 10, Jena, Germany ${ }^{3}$ Lawrence Berkeley National Laboratory, Berkeley, California, USA

${ }^{4}$ LSCE, UMR8212 CEA/CNRS/UVSQ, Université Paris Saclay, Gif-sur-Yvette, France

${ }^{5}$ Université de Rennes, CNRS, Géosciences Rennes, UMR 6118, F-35000 Rennes, France

${ }^{6}$ Melnikov Permafrost Institute, Siberian Branch, Russian Academy of Sciences, Yakutsk, Russia

*Corresponding author. laure.gandois@ensat.fr

\section{ABSTRACT}

Permafrost peatlands are important carbon stocks currently experiencing rapid evolution after permafrost thaw. Following thaw, dissolved organic matter (DOM) is a potentially important pathway for the release of permafrost carbon. This study investigates the origin and composition of DOM across sites at different stages of thaw in a discontinuous permafrost area of North Siberia. We determine the optical properties, molecular composition, stable $\left(\delta^{13} \mathrm{C}\right)$ and radiocarbon $\left({ }^{14} \mathrm{C}\right)$ content of DOM. Early stages of thaw are characterized by high DOC concentrations, high aromaticity, contribution of vegetation-derived DOM, and a high contribution of permafrost carbon. In contrast, in later stages, the microbial contribution to DOM increases, and only modern carbon is detected. This work links DOM composition with its radiocarbon content in permafrost peatlands. It shows that DOM originating from previously 
frozen permafrost peatland is highly aromatic and previously processed. It highlights the variability of post-thaw carbon dynamics in boreal and arctic ecosystems.

KEYWORDS: Permafrost peatlands, Thermokarst Bogs, Dissolved Organic Matter, Radiocarbon, Optical properties of DOM, Molecular composition of DOM, Siberia

\section{Introduction}

In warming boreal and arctic regions, permafrost thaw is expected to affect ecosystems storing half of the global soil organic carbon stock ${ }^{1}$. Permafrost thaw, a deepening of the active layer or complete disappearance of frozen layers, exposes this carbon stock to microbial decomposition. The potential release of this large sequestered organic carbon stock into the active carbon cycle as a result of warming could be a significant positive feedback to climate change $^{2-4}$. Dissolved organic matter (DOM) is the most dynamic but least characterized carbon pool in boreal and arctic terrestrial ecosystems, and is a potentially important conduit for the release of permafrost carbon following thaw. Estimates of DOM transfer from large Arctic

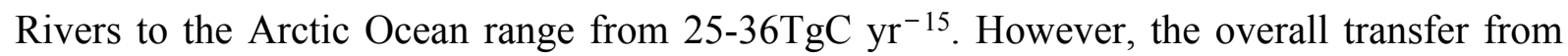
terrestrial ecosystems to surface water is higher, as a fraction of DOM is mineralized or buried in sediments before reaching the Arctic Ocean ${ }^{6}$. These processes are highly dependent on DOM composition. Therefore, investigating the composition, carbon origin, and potential lability of DOM is crucial to understand the strength of potential feedbacks to climate change as a result of permafrost thaw ${ }^{7}$. In landscapes dominated by permafrost degradation, radiocarbon $\left({ }^{14} \mathrm{C}\right)$ measurements of the carbon released as DOM provide a powerful tool to identify shifts in carbon origin. In particular, they can help identify old permafrost-derived carbon, or carbon which has been more recently fixed from the atmosphere by vegetation, with very different implications for feedback to climate. 
To date, most studies of radiocarbon content of DOM in the boreal and arctic areas have 50 focused on rivers and streams ${ }^{5,8,9}$. At the outlet of large Arctic Rivers, the majority of organic carbon exported during the spring flood is young carbon. Older carbon, which may reflect permafrost thaw and/or deeper water flows is exported during low flow periods ${ }^{5,10}$, and also found upstream in the fluvial network ${ }^{6}$. Despite the important role of headwaters, little research has been done in upstream catchments to characterize DOM composition and origin, or to track permafrost carbon in DOM before its signal disappears as a result of dilution, photodegradation and/or microbial consumption ${ }^{11}$.

Permafrost peatlands are disproportionally important landscapes to study permafrost degradation, as they show the highest carbon density of boreal and artic soil, and store at least one third of the permafrost soil organic carbon stocks ${ }^{1,12}$. Furthermore, their degradation as a result of permafrost thaw has increased in recent decades ${ }^{13,14}$. Following permafrost thaw, ground subsidence and changes in hydrological pathways often lead to the formation of small thermokarst bogs nested in permafrost peatland mounds (palsa), then to larger bogs, and ultimately to inundated fens ${ }^{15}$. The composition of DOM evolves with this ecosystem transition, reflecting the increased contribution of new vegetation ${ }^{16}$, microbial activity ${ }^{17,18}$, and the transition from bog to fen ${ }^{19}$.

Although carbon-rich permafrost peatlands account for $19 \%$ of permafrost area ${ }^{15,20}$, the links between DOM composition, lability and origin have not been established in this context. Permafrost soils have a wide variety of formation histories and geologies ${ }^{21}$, with important implications for organic matter composition and degree of processing prior to thaw, and potential lability after thaw ${ }^{20,22}$. For example, in studies of ice-rich Yedoma permafrost, ancient organic matter locked in permafrost contained high levels of small molecular weight organic acids, characterized by a low aromaticity, and was highly labile. It was therefore rapidly consumed by microorganisms and released to the atmosphere after thaw ${ }^{11,23}$. The link between 
permafrost-derived carbon in DOM and its composition remains underexplored in peatland permafrost context.

In a discontinuous permafrost area in Northern Siberia, where permafrost peatland degradation has been recently documented, we investigate the evolution of DOM using a combination of analytical techniques from the bulk (isotopic and optical) to molecular scale, in combination with radiocarbon measurements, which are indicative of the age and origin of DOM, across thermokarst bogs and lakes of different sizes and degrees of thaw. The objectives of this study are (1) to characterize DOM composition in a thawing permafrost landscape and (2) to evaluate the influence of permafrost carbon on the composition of DOM.

\section{Material \& Methods}

\section{Study site}

The study area is located near Igarka (Figure 1a), on the eastern bank of the Yenisei River $\left(67^{\circ} 27^{\prime} 11^{\prime} ' \mathrm{~N}, 86^{\circ} 32^{\prime} 07^{\prime}\right.$ 'E), in a region of discontinuous permafrost. The mean annual air temperature from $1980-2010$ is $-7.7 \pm 1.1{ }^{\circ} \mathrm{C}$ and the mean annual precipitation is $632 \pm 86$ $\mathrm{mm}$, including $320 \pm 50 \mathrm{~mm}$ in the form of snow ${ }^{24}$. Sampling focused on the Graviyka catchment (Figure 1b). The Graviyka River, with watershed of $320 \mathrm{~km}^{2}$, is one of the northernmost tributaries of the Yenisei River. It is mainly covered by forest, dominated by larch (Larix siberica), birch (Betula pendula), and Siberian pine (Pinus siberica), and palsa landscapes (frozen peat mounds). The palsa landscapes are dominated by moss, lichens and small birch. Degraded areas affected by permafrost thaw are characterized by depression (thermokarsts), where thermokarst bogs dominated by Sphagnum spp. and Eriophorum spp develop. The land cover is an indicator of the permafrost status and the depth of the active layer (seasonally thawed soil layer). Forested areas tend to have a deep active layer thickness associated with Pleistocene permafrost, while palsa dominated landscapes are indicative of the presence of Holocene permafrost, with a shallower active layer depth. At our study site, peatland accumulation began 
99 during the mid-Holocene ${ }^{25,26}$, likely between 4 to $5 \mathrm{kyr}$ BP. North of Igarka, permafrost 100 aggradation and palsa formation occurred between 3.5 and $2.5 \mathrm{kyr}$ during a period of a period 101 of relatively cooler temperatures ${ }^{27}$. At our site, radiocarbon data acquired close to the active 102 layer depth are consistent with these findings, and suggest that permafrost aggradation may 103 have begun around 2.8 ka (Figure SI.1). Permafrost degradation, characterized by the increase 104 of the active layer and in the region surrounding Igarka has been observed for the last 30 years $105 \quad 24$.

\section{Sample collection}

In the thawing palsa areas surrounding Igarka, we sampled sites at different stages of thaw in July 2015 and July 2016, including thermokarst bogs of various sizes, a fen, and thermokarst lakes. Thermokarst bogs form in depressions where palsa thaws and collapses. At the beginning of thaw process, small thermokarst bogs form, perched on palsa mounds. As the

111 thaw process progresses, the size of thermokarst bogs increases. A continuation of the thaw 112 process leads to the formation of fens ${ }^{15,28,29}$. In addition to the size of thermokarst features, the 113 different thaw stages are characterized by differences in dominant vegetation, with a shift from plant communities which prefer dry growing conditions to those which prefer wet growing conditions $^{15,16,29}$.

These selected sites were not intended to represent a time-since-thaw chronosequence. Instead, they were selected to represent a range of thaw-affected landscapes present in the region, from those least affect by thaw (small bogs), to larger thermokarst features which do not retain permafrost (fen and lakes). Our sampling follows the classification defined by

120 Hodgkins et al. (2016) ${ }^{16}$, with adaptations to our site. We sampled "small bogs", thermokarst 121 bogs perched on palsa, with a size $<40 \mathrm{~m}^{2}$ (corresponding to "recently thawed palsa"). We also 122 sampled "large bogs", which were $>100 \mathrm{~m}^{2}$ and adjacent to small amounts of remaining palsa 123 (corresponding to "thawing Sphagnum-dominated bogs"). The surface area of the sampled bogs 
124 was determined based on field measurements for the smallest bogs, and using Google Earth for

125 the larger bogs. A large (area $\left.\sim 3000 \mathrm{~m}^{2}\right)$ thermokarst bog developed in a mineral soil context

126 was also sampled as a reference free from permafrost peatland carbon (referred to as MB or

127 "mineral-context bog"). All the sampled bogs are colonized by Sphagnum, and the large bogs

128 included Eriophorum. We also sampled a fen, in which both Sphagnum and Carex are found.

129 In all thermokarst bogs, porewater profiles were collected in the active layer and to maximum

130 depth of $2 \mathrm{~m}$ using narrow piezometers $(0.64 \mathrm{~cm}$ diameter $)$ connected to a hand pump.

131 Following in situ $\mathrm{pH}$ and conductivity measurements, samples were filtered using pre-

132 combusted GF/F filters and stored in cleaned (acid washed and combusted) amber glass bottles

133 for DOC, $\delta{ }^{13} \mathrm{C}-\mathrm{DOC},{ }^{14} \mathrm{C}$-DOM, molecular and optical properties of DOM.

134

135

\section{Sample analyses and calculations}

\subsection{DOC concentrations}

Non-purgeable organic carbon (NPOC, referred to hereafter as DOC) was analyzed on filtered (GF/F Whatman) samples after acidification to $\mathrm{pH} 2(\mathrm{HCl})$ with a TOC-V CSH analyzer (Shimadzu, Japan), with a quantification limit of $1 \mathrm{mg} \mathrm{L}^{-1}$. Certified materials (ion 915 and ion 96.4, Environment and Climate Change Canada, Canada) were included in the analytical loop and recovery was $>95 \%$ of the certified value.

\subsection{Optical properties of DOM}

The UV absorption spectra from 240 to $700 \mathrm{~nm}$ of porewater were measured with a spectrophotometer (Secoman UV light XT5), in a $1 \mathrm{~cm}$ quartz cell. The baseline was determined with ultra-pure water. The Specific UV Absorbance at $254 \mathrm{~nm}\left(\mathrm{SUVA}_{254}, \mathrm{~L} \mathrm{mg}^{-1} \mathrm{~m}^{-1}\right)$ was calculated as follows: $\mathrm{SUVA}=\mathrm{A}_{254} / \mathrm{b} *[\mathrm{DOC}]\left(\mathrm{L} \mathrm{mg}^{-1} \mathrm{~m}^{-1}\right)$, where $\mathrm{A}_{254}$ is the sample absorbance at $254 \mathrm{~nm}$ (non-dimensional), $\mathrm{b}$ is the optical path length $(\mathrm{m})$ and DOC is in $\mathrm{mg} \mathrm{\textrm {L } ^ { - }}$

1. SUVA is a proxy for DOM aromaticity ${ }^{30}$. Fluorescence measurements were performed using 
148 a spectrofluorometer (Synergy MX, Biotek). The emission spectrum was recorded for a $370 \mathrm{~nm}$

149 excitation wavelength. The fluorescence Index (FI) was determined for a $370 \mathrm{~nm}$ excitation

150 wavelength, as the ratio of the $470 \mathrm{~nm}$ emission and $520 \mathrm{~nm}$ emission, as defined by McKnight 151 et al. $(2001)^{31}$ and Jaffé et al $(2008)^{32}$. Potential additional absorbance related to Fe content was 152 checked on a few samples following the procedure described by Poulin et $\mathrm{al}^{33}$. The additional 153 absorbance $1.4 \pm 1.6 \%$ across all samples where Fe was measured, and was therefore neglected.

\subsection{Stable isotopes analysis}

The $\delta^{13} \mathrm{C}$-DOC was analyzed at the UC Davis stable isotope facility. The analyses were performed using a O.I. Analytical Model 1030 TOC Analyzer (Xylem Analytics, College Station, TX) interfaced to a PDZ Europa 20-20 isotope ratio mass spectrometer (Sercon Ltd., Cheshire, UK) utilizing a GD-100 Gas Trap Interface (Graden Instruments). Reference materials included IAEA-600, USGS-40, USGS-41, Elemental Microanalysis (EM) reference materials, and NIST 8559, 8560, and 8561. The replicates analysis showed an average of 0.25

161 variation, i.e $0.16 \%$.

\subsection{Radiocarbon analysis and calculation of permafrost carbon contribution}

The radiocarbon content of DOM and soil organic matter (SOM) was measured on selected

164 freeze-dried samples at the LSCE laboratory (GifA and ECHo) on the MICADAS compact

165 AMS system ${ }^{34}$. From 2 to 4 samples per profile were analyzed. DOM samples were analyzed 166 through the EA-GIS coupling ${ }^{35}$. For SOM values, bulk samples were analyzed. For DOM, the

167 freeze-dried powder was analyzed. The $\delta^{13} \mathrm{C}$ value of the freeze-dried powder was compared to 168 the direct analysis of $\delta^{13} \mathrm{C}$-DOM on the liquid sample after acidification, to evaluate the need

169 for removal of inorganic carbon. Typically, $0.5 \mathrm{mg}$ of sample material was prepared in a tin capsule, and acidified with $3 \mu \mathrm{L}$ of $\mathrm{HCl} 1 \mathrm{M}$. All samples were duplicated, and reproducibility

171 of duplicates was checked (Chi2 test). Blanks and standard material (C7 and OXA2 oxalic acid) 
were included in the analysis sequence. All ${ }^{14} \mathrm{C}$ results were corrected for isotopic fractionation according to the conventions of Stuiver et al $(1977)^{36}$ and reported as $\mathrm{F}^{14} \mathrm{C}$ following the recommendation of Reimer et al. $(2004)^{37}$.

In order to assess the contribution of permafrost carbon to individual DOM samples, a two component mixing model (permafrost and atmospheric pools) was applied to the bulk $\mathrm{F}^{14} \mathrm{C}$ content. The permafrost pool was determined based on 3 samples from deep frozen palsa (3 to 4 meters, SI), with an average radiocarbon content of $\mathrm{F}^{14} \mathrm{C}=0.608 \pm 0.022(4000 \pm 290 \mathrm{BP})$. For the atmospheric pool, 36 independent calculations were performed to represent different possible atmospheric end members, as the radiocarbon content in the atmosphere has changed slightly. Plant material derived from recent photosynthesis will therefore likely represent a mix of these values, including vegetation grown over a range of recent years. Our calculations used atmospheric end members which ranged from the average atmospheric signature from 1980 to $2015\left(\mathrm{~F}^{14} \mathrm{C}=1.12\right.$; represents a mix of vegetation inputs over the time period) to a pure 2015 signal $\left(\mathrm{F}^{14} \mathrm{C}=1.02\right.$; input from the most recent 2015 vegetation only) ${ }^{38}$ to account for the possibility of a mix of recent inputs. The proportion of permafrost carbon calculated as follows:

$$
\alpha_{\text {perm }}=\frac{\left(F 14 C_{\text {mes }}-F 14 C_{\text {Atmo }}\right)}{\left(F 14 C_{\text {Perm }}-F 14 C_{\text {Atmo }}\right)}
$$

\subsection{Molecular analysis and molecular indicators calculations}

In order to specifically track permafrost influence on DOM composition, a subset of samples was selected based on their ${ }^{14} \mathrm{C}$ content for molecular analysis. The thermochemolysis using tetramethylammonium hydroxide coupled to gas chromatography and mass spectrometry (THM-GC-MS) was performed according to Jeanneau et al., (2014) ${ }^{39}$. Briefly, approximately $1 \mathrm{mg}$ of freeze-dried solid residue was introduced into an $80 \mu \mathrm{L}$ stainless steel reactor with an excess of tetramethylammonium hydroxide $(6 \mathrm{mg})$. THM reaction was performed on-line using a vertical micro-furnace pyrolyzer PZ-2020D (Frontier Laboratories, Japan) operating at 
$400^{\circ} \mathrm{C}$. The products of this reaction were injected into a gas chromatograph (GC) GC-2010 (Shimadzu, Japan) equipped with a SLB 5MS capillary column in the split mode $(60 \mathrm{~m} \times 0.25$ $\mathrm{mm}$ ID, $0.25 \mu \mathrm{m}$ film thickness). Compounds were detected using a QP2010+ mass spectrometer (MS) (Shimadzu, Japan) operating in the full scan mode. The list of analyzed compounds and $\mathrm{m} / \mathrm{z}$ ratios used for their integration are given in the supplementary materials (Table SI.1). Compounds were identified on the basis of their full-scan mass spectra by comparison with the NIST library and with published data ${ }^{40}$.

The peak area of the selected $\mathrm{m} / \mathrm{z}$ (mass/charge) for each compound was integrated and corrected by a mass spectra factor calculated as the reciprocal of the proportion of the fragment used for the integration and the entire fragmentogram provided by the NIST library. The proportion of each compound class was calculated by dividing the sum of the areas of the compounds in this class by the sum of the peak areas of all analyzed compounds expressed as a percentage. The analytical uncertainty for this analytical method, expressed as a relative standard deviation, ranged from 10 to $20 \%$ depending on the samples and the target compounds. diacids containing from 4 (fumaric and succinic acids) to 6 (methylglutaric acid) carbon atoms, phenolic compounds (PHE) including lignin and tannin markers, carbohydrates (CAR) (deoxysaccharinic acids produced by the THM of free monosaccharrides and terminal 214 monosaccharides from polysaccharides) ${ }^{41}$ and fatty acids (FA), from 8 to 30 carbon atoms. The 215 distribution of target compounds in these categories was used to investigate DOM origin (plant vs microbial origin). The distribution of LMWFA (low molecular weight fatty acids, $<\mathrm{C} 18$ ) was used as an indication of microbial activity. With the exception of n-C16 and n-C18 that can derive from plant-derived input, LMWFA with more than 13 carbon atoms are known as 219 phospholipid fatty acids and serve as specific microbial biomarkers ${ }^{42}$. The proportion of plant220 derived compounds (\%VEG) was calculated using the deoxyC6/C5 ratio ${ }^{43}$ and the proportion 
of plant-derived fatty acids calculated as the proportion of HMW FA among FA excluding n-

$222 \mathrm{C} 16$ and n-C1839. Ratios of cinnamyl to vanillyl units $(\mathrm{C} / \mathrm{V})$ and of aldehyde to acid moieties 223 for vanillyl $\left((\mathrm{Al} / \mathrm{Ac})_{\mathrm{V}}\right)$ and syringyl $\left((\mathrm{Al} / \mathrm{Ac})_{\mathrm{S}}\right)$ depend on their botanical origin or, if the 224 botanical origin can be assumed to be constant, on their biodegradation state. As the botanical 225 origins of our samples were homogeneous, their ratios were used as biodegradation indices 226 based on the preferential biodegradation of (i) cinnamyl moieties and (ii) aldehydes among 227 vanillyl and syringyl units ${ }^{44,45}$.

\section{Statistical analysis}

Statistical analysis was performed using $\mathrm{R}^{46}$ and the Rstudio software (Version 1.2.1335), using ggplot ${ }^{47}$, dplyr ${ }^{48}$, dunn.test ${ }^{49}$ packages. Significant differences $(\alpha<0.05)$ between groups were performed using Kruskall Wallis and Dunn's post hoc multiple test.

\section{Results \& Discussion}

\section{Evolution of DOM composition along a permafrost thaw gradient}

We observe clear changes in both DOC concentration and DOM composition following permafrost peatland degradation (Table $1 \& 2$, Figure 2). These are associated with a specific DOM composition as indicated by consistent isotopic, optical and molecular analyses. Significant relationships were observed between bulk optical properties and molecular analysis.

238 The SUVA index was positively correlated to $\%$ PHE $\left(r^{2}=0.48 ; p<0.05\right)$ and phenol ratios $239\left((\mathrm{Al} / \mathrm{Ac})_{\mathrm{V}}\right.$ given as an example, $\left.\mathrm{r}^{2}=0.47 ; \mathrm{p}<0.05\right)$ while FI was positively correlated to the 240 percentage of low molecular weight fatty acids (LMWFA) $\left(r^{2}=0.5 ; p<0.05\right)$ and negatively 241 with the calculated percentage of vegetation origin $\left(r^{2}=0.42 ; p<0.05\right)$. concentrations $\left(44.1 \pm 10.1 \mathrm{mg} \mathrm{L}^{-1}\right)$, (Table 1, Figure 2). In these small thermokarst bogs, DOM

244 originates from vegetation and is highly aromatic. This is revealed by significantly lower 
245 fluorescence index values $(1.35 \pm 0.06)^{50}$, higher value of the $\%$ VEG index, and higher SUVA 246 index values $\left(5.4 \pm 0.6 \mathrm{~L} \mathrm{mg}^{-1} \mathrm{~m}^{-1}\right)$. This corresponds to almost $40 \%$ aromatic moieties ${ }^{30}$, 247 consistent with a higher proportion of phenols (PHE). The high $\delta^{13} \mathrm{C}-\mathrm{DOC}$ values ($24827.7 \pm 0.3 \%$ ) we observe in small thermokarst bogs are also typical of terrestrial SOM, which 249 has been through oxidation processes. This is further confirmed by lower values of $(\mathrm{Al} / \mathrm{Ac})_{\mathrm{V}}$, $250(\mathrm{Al} / \mathrm{Ac})_{\mathrm{S}}$ and $\mathrm{C} / \mathrm{V}{ }^{51,52}$. The significant correlations of $(\mathrm{Al} / \mathrm{Ac})_{\mathrm{S}}$ with $\mathrm{C} / \mathrm{V}\left(\mathrm{r}^{2}=0.82 ; \mathrm{p}=0.001\right)$ 251 and $(\mathrm{Al} / \mathrm{Ac})_{\mathrm{V}}\left(\mathrm{r}^{2}=0.83 ; \mathrm{p}=0.01\right)$ underline the consistency between these three ratios, which supports their use as biodegradation indices (Figure SI 2).

Along the thaw gradient, in larger thermokarst bogs as well as sites that have transitioned to fens and lakes, the composition and origin of DOM evolves. DOC concentrations decrease to $16.7 \pm 1.2 \mathrm{mg} \mathrm{L}^{-1}$ in large bogs to $11.0 \pm 2.4 \mathrm{mg} \mathrm{L}^{-1}$ in fens. Slightly higher values are measured in thermokarst lakes $\left(14.0 \pm 4.0 \mathrm{mg} \mathrm{L}^{-1}\right)$ and in the bog developed in mineral soil context $\left(12.9 \pm 2.3 \mathrm{mg} \mathrm{L}^{-1}\right)$. Dissolved organic matter composition evolves, with an increased proportion of microbially-derived compounds in large bogs, fens, and thermokarst lakes. This is evidenced by the increase in the fluorescence index values. The aromaticity of DOM decreases from 60 to $25 \%$, as indicated by the SUVA index. The $\delta^{13} \mathrm{C}$-DOC values also decrease to $-30 \%$, reaching relatively depleted values, closer to recently produced vegetation, and indicative of lower rates of processing.

Shifts of DOM composition after permafrost thaw have been reported at other boreal and arctic sites. They have been related to photodegradation, microbial activity, or change of vegetation. Laurion and Mladenov (2013) $)^{53}$ showed that in the case of thawing ponds in the

266 Canadian high Arctic, UV mostly transformed aromatic and terrestrially derived DOM into more labile molecules. More precisely, an FT-ICR-MS study of the phototransformation of 268 DOM originating from the active layer and permafrost in Alaska ${ }^{54}$, showed that a small 269 proportion of molecules, holding carboxylic groups, participated in photo-oxidation. However, 
in the context of thermokarst bogs, photo-oxidation is likely to be highly limited since a

271

272

273 vegetation mat covers the surface, and this process is only likely to occur in open water. In Central Siberia ${ }^{17}$, a decrease in the DOC concentration in thermokarst lakes was linked with a decrease in the size of organic molecules. Pokrovsky et al. (2011) ${ }^{17}$ attributed this trend to the progressive consumption of DOM by heterotrophic bacteria and release of exometabolites by phytoplankton. Hodgkins et al (2016) ${ }^{16}$ also reported a shift in the elemental and optical properties of DOM along a permafrost thaw gradient from thermokarst bog to fen in Sweden. The primary changes observed between the early stages of palsa thaw and the fen was the decrease of tannin-like and high $\mathrm{O} / \mathrm{C}$ compounds and the increase of microbially derived DOM. These differences were mainly attributed to the presence or absence of sphagnum. In our study, a similar shift from terrestrial to microbially-derived DOM is observed from thermokarst bogs to fen, although sphagnum was present at all sites. We demonstrate in this study that the origin of DOM, traced using ${ }^{14} \mathrm{C}-\mathrm{DOM}$, also contributes to the shift in DOM composition.

\section{Peatland permafrost influence on DOM composition: Link to potential lability}

We observe that the contribution of permafrost carbon to DOM decreases along the thaw gradient, and controls DOM composition. This is revealed by the evolution of the radiocarbon content of DOM (Figure 3a\&b). The lowest values of $\mathrm{F}^{14} \mathrm{C}$ of DOM are measured in small thermokarst bogs $\left(\mathrm{F}^{14} \mathrm{C}=0.799 \pm 0.008(1800 \pm 85 \mathrm{BP})\right)$, which correspond to a contribution of 40 to $60 \%$ permafrost carbon. In large thermokarst bogs, the $\mathrm{F}^{14} \mathrm{C}$ value covers a wide range of values, depending on sample depth (from $\mathrm{F}^{14} \mathrm{C}=0.842 \pm 0.005(1385 \pm 45 \mathrm{BP}$ ) to $\mathrm{F}^{14} \mathrm{C}=1.043 \pm 0.005$, modern carbon), with a higher contribution of permafrost carbon in deep layers. In thermokarst lakes, surface samples are characterized by modern DOM (permafrost contribution does not exceed $10 \%)$, while old $\mathrm{DOM}\left(\mathrm{F}^{14} \mathrm{C}=0.854 \pm 0.008,1275 \pm 70 \mathrm{BP}\right)$ is measured in sediment porewater at a depth of $1 \mathrm{~m}$. In the thermokarst bog developed in the mineral context, modern DOM is analyzed to depths of $2 \mathrm{~m}$, and slightly lower values are 
measured $\left(\mathrm{F}^{14} \mathrm{C}=0.958 \pm 0.008,350 \pm 65 \mathrm{BP}\right)$. No calculation is performed for the bog developed on mineral soils, since the permafrost signature for the mineral context was not measured.

We observe that the amount of permafrost peatland carbon remaining in the sampled DOM directly influences DOM composition (Figure 4). A significant negative correlation is observed between ${ }^{14} \mathrm{C}$-DOM and FI, as well as the percentage of vegetation. A positive correlation is highlighted between ${ }^{14} \mathrm{C}-\mathrm{DOM}$ and SUVA index and $\mathrm{PHE}$ ratios $\left((\mathrm{Al} / \mathrm{Ac})_{\mathrm{V}}\right.$ given as an example). This reveals that a higher proportion of permafrost carbon in DOM is associated with a larger proportion of plant-derived DOM, higher aromaticity and a higher degradation state of phenols. As the proportion of permafrost carbon decreases, the microbial contribution to DOM increases.

The fact that only modern DOM is detected in fens and thermokarst lakes could mean that permafrost-derived DOM has been transferred to the fluvial network, has been diluted by modern sources of DOM in the ecosystem or has been processed on site. At our study site, no surface water connection is observed between the small and large thermokarst bogs and the fluvial network, so it is unlikely that it is transferred to surface waters. Our results suggest that

311 the lability of permafrost peatland derived DOM is limited. Biodegradability of DOM is not 312 strictly determined by its chemical composition, but also depends on environmental factors, 313 such as nutrients, oxygen content or temperature ${ }^{7,55}$. DOM composition and the anoxic 314 conditions may have suppressed the mineralization rate of permafrost DOM, potentially explaining its high proportion in deep layers of thermokarst bogs. However, several studies

316 have linked higher degradability of DOM to lower aromaticity $6,7,11,56$, and lower degradation 317 states of phenols ${ }^{6,57}$, inferring limited lability of peatland permafrost DOM at our site. However, 318 since no direct measurement were made, the fate of DOM originating from permafrost remains 319 uncertain. In Canada, only modern carbon was measured in $\mathrm{CO}_{2}$ emitted from both young and 
mature thermokarst bogs $^{58}$, showing that mineralization of permafrost carbon in the case of

321 thermokarst bogs was limited. In the fen and thermokarst lakes, we detect only modern,

322 microbially dominated DOM. However, we cannot differentiate between dilution of the

323 permafrost signal by this modern source of DOM and on-site processing of DOM. These two

324 processes would both result in the same observation of more modern carbon (increasing

325 radiocarbon content) with decreasing DOC concentrations (Figure SI.3). Further work to address this ambiguity and confirm the low lability we infer from our analysis in permafrost peatlands should include the additional investigation of biodegradable DOC $^{59}$, as well as measurements of the ${ }^{14} \mathrm{C}$ content of GHGs emitted from permafrost peatlands ${ }^{60}$.

3. DOM composition and ${ }^{14} \mathrm{C}$ content: Variability across geological context and spatial scales in the Arctic

Our work links the DOM composition with its ${ }^{14} \mathrm{C}$ content in the context of permafrost peatlands. Establishing this link between the ${ }^{14} \mathrm{C}-\mathrm{DOM}$ (and therefore the permafrost carbon contribution to DOM) and its composition is key to assessing the potential feedback of permafrost thaw to climate change. In the Arctic, fewer studies have coupled radiocarbon content of DOM to its molecular or elemental composition ${ }^{5,11,61}$, compared to the optical properties of DOM 5,9,11,18,61,62. Establishing a relationship between these cheap and widely measured parameters and ${ }^{14} \mathrm{C}$ content would allow more widespread assessment of the release 338 of old permafrost carbon following thaw. In addition, our study highlights significant relationships between SUVA and the molecular composition of DOM, especially phenol content and their degradation state, increasing the information given by such an optical index.

341 Such relationships have been established in Alaska, for the hydrophobic fraction of DOM, with older DOM being associated with lower SUVA9. 
345 DOM (Figure 5). In existing Arctic studies, none of which were conducted on permafrost 346 peatlands, a larger permafrost influence (lower radiocarbon content) correlates with lower 347 SUVA values, indicating a lower aromaticity and higher lability ${ }^{6}$ (Figure 5 and Table 3 ). In the 348 case of the Yenisei catchment in Siberia, shifts of DOM bulk age are related to hydrology, with 349 young DOM being exported during spring snowmelt. This spring DOM originates from the 350 flushing of fresh litter and shallow organic soil layers, and therefore has a more aromatic composition $^{10}$. In the context of Yedoma, permafrost has been shown to have sequestered high content of aliphatic and small organic acids. For example in an Alaskan core, $24 \%$ of permafrost dissolved organic carbon was found in the form of highly labile acetate ${ }^{63}$, consumed within days. This explains the low SUVA associated with the older samples, and the high lability ${ }^{6}$. In the case of high Canadian Arctic ponds ${ }^{18}$, DOM from thawing ponds is a mixture of old DOM and autochthonous DOM, resulting in a low apparent SUVA of old DOM.

The apparent contradiction between the trends in these studies and our own observations (Figure 5) can likely be explained by the geological context, permafrost history and scale of our study. In addition, the peatland type $\mathrm{e}^{20}$ and the history of permafrost formation ${ }^{22}$ could influence 360 organic matter composition and lability in permafrost peatlands. At our study site, peatland 361 formation during the Holocene was followed by permafrost aggradation ${ }^{27}$. Therefore, the

362 formation of permafrost likely froze highly aromatic organic matter, which is typical of 363 peatlands. This organic matter might have already undergone microbial processing over long 364 periods, perhaps further increasing the aromaticity of $\mathrm{DOM}^{64}$. This would explain the observed 365 characteristics of old bulk DOM in our study, and a potentially lower lability of peatland 366 permafrost $\mathrm{DOM}^{22}$. This is in agreement with a recent study in central Siberia showing that 367 DOM from previously frozen peat was highly refractory ${ }^{65}$. This highlights the unique nature of 368 permafrost peatlands (19\% of permafrost area, $70 \%$ in Eurasia, and more than one third of the 369 organic carbon stocks ${ }^{12}$ ) with regards to post thaw organic carbon dynamics, in comparison to 
370

371

372

373

374

375

376

377

378

379

380

381

382

383

384

mineral soils in the Arctic. This study indicates that a runaway feedback of old labile carbon released as a result of permafrost thaw should not be expected in all cases. In peatland permafrost, our results suggest that thawing carbon is highly aromatic, and might have undergone previous microbial processing prior to permafrost aggradation. Permafrost peatlands are therefore relatively unlikely to release labile DOM as a result of permafrost thaw.

\section{ACKNOWLEDGMENT}

This study was funded by CNRS - INEE through the PEPS program 'Blanc' 2015. Travels to Igarka were supported by the SMI program of INPT. Additional support was provided by the ERANet-LAC joint program (METHANOBASE ELAC2014_DCC-0092). A. Hoyt was funded by the European Research Council (ERC) EU Horizon 2020 Programme (grant No. 695101) and by the MIT-Russia Program of the MIT International Science and Technology Initiative (MISTI). The DOC analysis were performed at the PAPC (Plateforme d'Analyse Physico-Chimique) at the EcoLab Laboratory. The authors thank Franck Gilbert for access to the spectofluorometer, Arnaud Mansat for the permafrost map, and Anatoly Pimov for valuable logistical assistance in the field. The authors thank tree anonymous reviewers for their constructive comments which improved the manuscript.

\section{SUPPORTING INFORMATION.}

Figure SI.1. Age of bulk OC in palsa mounts. Figure SI.2. Relationships between phenol ratios. Figure SI.3 Plot of ${ }^{14} \mathrm{C}$ content versus DOC concentrations. Table SI.1. List of analyzed compounds and $\mathrm{m} / \mathrm{z}$ ratios used for their integration. This information is available free of charge via the Internet at http://pubs.acs.org

\section{REFERENCES}


393

394

395

396

397

398

399

400

401

402

403

404

405

406

407

408

409

410

411

412

413

414

415

416

417

418

419

420

421

422

423

424

425

426

427

428

429

430

431

432

433

434

435

436

437

438

439

440

441
(1) Hugelius, G.; Strauss, J.; Zubrzycki, S.; Harden, J. W.; Schuur, E. a. G.; Ping, C.-L.; Schirrmeister, L.; Grosse, G.; Michaelson, G. J.; Koven, C. D.; et al. Estimated Stocks of Circumpolar Permafrost Carbon with Quantified Uncertainty Ranges and Identified Data Gaps. Biogeosciences 2014, 11 (23), 6573-6593. https://doi.org/10.5194/bg-116573-2014.

(2) Schuur, E. A. G.; Bockheim, J.; Canadell, J. G.; Euskirchen, E.; Field, C. B.; Goryachkin, S. V.; Hagemann, S.; Kuhry, P.; Lafleur, P. M.; Lee, H.; et al. Vulnerability of Permafrost Carbon to Climate Change: Implications for the Global Carbon Cycle. BioScience 2008, 58 (8), 701. https://doi.org/10.1641/B580807.

(3) Ciais, P.; Sabine, G.; Bala, G.; Bopp, L.; Brovkin, V.; Canadell, J. G.; Chhabra, A.; DeFries, R. S.; Galloway, J.; Heimann, M.; et al. Carbon and Other Biogeochemical Cycles. In: Climate Change 2013: The Physical Science Basis. In Contribution of Working Group I to the Fifth Assessment Report of the Intergovernmental Panel on Climate Change; Cambridge, United Kingdom and New York, NY, USA., 2013.

(4) Schuur, E. A. G.; McGuire, A. D.; Schädel, C.; Grosse, G.; Harden, J. W.; Hayes, D. J.; Hugelius, G.; Koven, C. D.; Kuhry, P.; Lawrence, D. M.; et al. Climate Change and the Permafrost Carbon Feedback. Nature 2015, 520 (7546), 171-179. https://doi.org/10.1038/nature14338.

(5) Amon, R. M. W.; Rinehart, A. J.; Duan, S.; Louchouarn, P.; Prokushkin, A.; Guggenberger, G.; Bauch, D.; Stedmon, C.; Raymond, P. A.; Holmes, R. M.; et al. Dissolved Organic Matter Sources in Large Arctic Rivers. Geochim. Cosmochim. Acta 2012, 94, 217-237. https://doi.org/10.1016/j.gca.2012.07.015.

(6) Mann, P. J.; Eglinton, T. I.; McIntyre, C. P.; Zimov, N.; Davydova, A.; Vonk, J. E.; Holmes, R. M.; Spencer, R. G. M. Utilization of Ancient Permafrost Carbon in Headwaters of Arctic Fluvial Networks. Nat. Commun. 2015, 6, 7856. https://doi.org/10.1038/ncomms8856.

(7) Abbott, B. W.; Larouche, J. R.; Jones, J. B.; Bowden, W. B.; Balser, A. W. Elevated Dissolved Organic Carbon Biodegradability from Thawing and Collapsing Permafrost. J. Geophys. Res. Biogeosciences 2014, 119 (10), $2014 \mathrm{JG} 002678$. https://doi.org/10.1002/2014JG002678.

(8) Raymond, P. A.; McClelland, J. W.; Holmes, R. M.; Zhulidov, A. V.; Mull, K.; Peterson, B. J.; Striegl, R. G.; Aiken, G. R.; Gurtovaya, T. Y. Flux and Age of Dissolved Organic Carbon Exported to the Arctic Ocean: A Carbon Isotopic Study of the Five Largest Arctic Rivers. Glob. Biogeochem. Cycles 2007, 21 (4), GB4011. https://doi.org/10.1029/2007GB002934.

(9) O’Donnell, J. A.; Aiken, G. R.; Walvoord, M. A.; Raymond, P. A.; Butler, K. D.; Dornblaser, M. M.; Heckman, K. Using Dissolved Organic Matter Age and Composition to Detect Permafrost Thaw in Boreal Watersheds of Interior Alaska. J. Geophys. Res. Biogeosciences 2014, 119 (11), 2155-2170. https://doi.org/10.1002/2014JG002695.

(10) Barnes, R. T.; Butman, D. E.; Wilson, H. F.; Raymond, P. A. Riverine Export of Aged Carbon Driven by Flow Path Depth and Residence Time. Environ. Sci. Technol. 2018, 52 (3), 1028-1035. https://doi.org/10.1021/acs.est.7b04717.

(11) Drake, T. W.; Wickland, K. P.; Spencer, R. G. M.; McKnight, D. M.; Striegl, R. G. Ancient Low-Molecular-Weight Organic Acids in Permafrost Fuel Rapid Carbon Dioxide Production upon Thaw. Proc. Natl. Acad. Sci. 2015, 112 (45), 13946-13951. https://doi.org/10.1073/pnas.1511705112.

(12) Tarnocai, C.; Canadell, J. G.; Schuur, E. a. G.; Kuhry, P.; Mazhitova, G.; Zimov, S. Soil Organic Carbon Pools in the Northern Circumpolar Permafrost Region. Glob. Biogeochem. Cycles 2009, 23 (2). https://doi.org/10.1029/2008GB003327. 
(13) Vallée, S.; Payette, S. Collapse of Permafrost Mounds along a Subarctic River over the Last 100 Years (Northern Québec). Geomorphology 2007, 90 (1), 162-170. https://doi.org/10.1016/j.geomorph.2007.01.019.

(14) Borge, A. F.; Westermann, S.; Solheim, I.; Etzelmüller, B. Strong Degradation of Palsas and Peat Plateaus in Northern Norway during the Last 60 Years. The Cryosphere 2017, 11 (1), 1-16. https://doi.org/10.5194/tc-11-1-2017.

(15) Swindles, G. T.; Morris, P. J.; Mullan, D.; Watson, E. J.; Turner, T. E.; Roland, T. P.; Amesbury, M. J.; Kokfelt, U.; Schoning, K.; Pratte, S.; et al. The Long-Term Fate of Permafrost Peatlands under Rapid Climate Warming. Sci. Rep. 2015, 5, 17951. https://doi.org/10.1038/srep17951.

(16) Hodgkins, S. B.; Tfaily, M. M.; Podgorski, D. C.; McCalley, C. K.; Saleska, S. R.; Crill, P. M.; Rich, V. I.; Chanton, J. P.; Cooper, W. T. Elemental Composition and Optical Properties Reveal Changes in Dissolved Organic Matter along a Permafrost Thaw Chronosequence in a Subarctic Peatland. Geochim. Cosmochim. Acta 2016, 187, 123140. https://doi.org/10.1016/j.gca.2016.05.015.

(17) Pokrovsky, O. S.; Shirokova, L. S.; Kirpotin, S. N.; Audry, S.; Viers, J.; Dupré, B. Effect of Permafrost Thawing on Organic Carbon and Trace Element Colloidal Speciation in the Thermokarst Lakes of Western Siberia. Biogeosciences 2011, 8 (3), 565-583. https://doi.org/10.5194/bg-8-565-2011.

(18) Wang, J.-J.; Lafrenière, M. J.; Lamoureux, S. F.; Simpson, A. J.; Gélinas, Y.; Simpson, M. J. Differences in Riverine and Pond Water Dissolved Organic Matter Composition and Sources in Canadian High Arctic Watersheds Affected by Active Layer Detachments. Environ. Sci. Technol. 2018, 52 (3), 1062-1071. https://doi.org/10.1021/acs.est.7b05506.

(19) Olefeldt, D.; Roulet, N. T. Effects of Permafrost and Hydrology on the Composition and Transport of Dissolved Organic Carbon in a Subarctic Peatland Complex. J. Geophys. Res. Biogeosciences 2012, 117 (G1), G01005. https://doi.org/10.1029/2011JG001819.

(20) Panneer Selvam, B.; Lapierre, J.-F.; Guillemette, F.; Voigt, C.; Lamprecht, R. E.; Biasi, C.; Christensen, T. R.; Martikainen, P. J.; Berggren, M. Degradation Potentials of Dissolved Organic Carbon (DOC) from Thawed Permafrost Peat. Sci. Rep. 2017, 7, 45811. https://doi.org/10.1038/srep45811.

(21) Treat, C. C.; Jones, M. C. Near-Surface Permafrost Aggradation in Northern Hemisphere Peatlands Shows Regional and Global Trends during the Past 6000 Years. The Holocene 2018, 28 (6), 998-1010. https://doi.org/10.1177/0959683617752858.

(22) Treat, C. C.; Jones, M. C.; Camill, P.; Gallego-Sala, A.; Garneau, M.; Harden, J. W.; Hugelius, G.; Klein, E. S.; Kokfelt, U.; Kuhry, P.; et al. Effects of Permafrost Aggradation on Peat Properties as Determined from a Pan-Arctic Synthesis of Plant Macrofossils. J. Geophys. Res. Biogeosciences 2016, 121 (1), 78-94. https://doi.org/10.1002/2015JG003061.

(23) Vonk, J. E.; Mann, P. J.; Davydov, S.; Davydova, A.; Spencer, R. G. M.; Schade, J.; Sobczak, W. V.; Zimov, N.; Zimov, S.; Bulygina, E.; et al. High Biolability of Ancient Permafrost Carbon upon Thaw: BIOLABILITY OF ANCIENT PERMAFROST CARBON. Geophys. Res. Lett. 2013, 40 (11), 2689-2693. https://doi.org/10.1002/grl.50348.

(24) Streletskiy, D. A.; Tananaev, N. I.; Opel, T.; Shiklomanov, N. I.; Nyland, K. E.; Streletskaya, I. D.; Tokarev, I.; Shiklomanov, A. I. Permafrost Hydrology in Changing Climatic Conditions: Seasonal Variability of Stable Isotope Composition in Rivers in Discontinuous Permafrost. Environ. Res. Lett. 2015, 10 (9), 095003. https://doi.org/10.1088/1748-9326/10/9/095003. 
(25) Rodionov, A.; Flessa, H.; Grabe, M.; Kazansky, O. A.; Shibistova, O.; Guggenberger, G. Organic Carbon and Total Nitrogen Variability in Permafrost-affected Soils in a Forest Tundra Ecotone. Eur. J. Soil Sci. 2007, 58 (6), 1260-1272. https://doi.org/10.1111/j.1365-2389.2007.00919.x.

(26) Kostyukevich, V. V. A Regional Geochronological Study of Late Pleistocene Permafrost. Radiocarbon. 1988, pp 477-486.

(27) Vasil'chuk, Y.; Vasil'chuk, A.; Jungner, H.; Budantseva, N.; Chizhova, J. Radiocarbon chronology of Holocene palsa of Bol'shezemel'skaya tundra in Russian North. https://ges.rgo.ru/jour/article/view/139 (accessed Jun 13, 2019).

(28) Liebner, S.; Ganzert, L.; Kiss, A.; Yang, S.; Wagner, D.; Svenning, M. M. Shifts in Methanogenic Community Composition and Methane Fluxes along the Degradation of Discontinuous Permafrost. Front. Microbiol. https://doi.org/10.3389/fmicb.2015.00356.

(29) Johansson, T.; Malmer, N.; Crill, P. M.; Friborg, T.; åKerman, J. H.; Mastepanov, M.; Christensen, T. R. Decadal Vegetation Changes in a Northern Peatland, Greenhouse Gas Fluxes and Net Radiative Forcing. Glob. Change Biol. 2006, 12 (12), 2352-2369. https://doi.org/10.1111/j.1365-2486.2006.01267.x.

(30) Weishaar, J. L.; Aiken, G. R.; Bergamaschi, B. A.; Fram, M. S.; Fujii, R.; Mopper, K. Evaluation of Specific Ultraviolet Absorbance as an Indicator of the Chemical Composition and Reactivity of Dissolved Organic Carbon. Environ. Sci. Technol. 2003, 37 (20), 4702-4708. https://doi.org/10.1021/es030360x.

(31) McKnight, D. M.; Boyer, E. W.; Westerhoff, P. K.; Doran, P. T.; Kulbe, T.; Andersen, D. T. Spectrofluorometric Characterization of Dissolved Organic Matter for Indication of Precursor Organic Material and Aromaticity. Limnol. Oceanogr. 2001, 46 (1), 38-48. https://doi.org/10.4319/1o.2001.46.1.0038.

(32) Jaffé R.; McKnight D.; Maie N.; Cory R.; McDowell W. H.; Campbell J. L. Spatial and Temporal Variations in DOM Composition in Ecosystems: The Importance of Long-term Monitoring of Optical Properties. J. Geophys. Res. Biogeosciences 2008, 113 (G4). https://doi.org/10.1029/2008JG000683.

(33) Poulin, B. A.; Ryan, J. N.; Aiken, G. R. Effects of Iron on Optical Properties of Dissolved Organic Matter. Environ. Sci. Technol. 2014, 48 (17), 10098-10106. https://doi.org/10.1021/es502670r.

(34) Synal, H.-A.; Stocker, M.; Suter, M. MICADAS: A New Compact Radiocarbon AMS System. Nucl. Instrum. Methods Phys. Res. Sect. B Beam Interact. Mater. At. 2007, 259 (1), 7-13. https://doi.org/10.1016/j.nimb.2007.01.138.

(35) Ruff, M.; Fahrni, S.; Gäggeler, H. W.; Hajdas, I.; Suter, M.; Synal, H.-A.; Szidat, S.; Wacker, L. On-Line Radiocarbon Measurements of Small Samples Using Elemental Analyzer and MICADAS Gas Ion Source. Radiocarbon 2010, 52 (4), 1645-1656. https://doi.org/10.1017/S003382220005637X.

(36) Stuiver, M.; Polach, H. A. Discussion Reporting of $<$ span Class="sup" $>14</$ span $>$ C Data. Radiocarbon 1977, 19 (3), 355-363. https://doi.org/10.1017/S0033822200003672.

(37) Reimer, P. J.; Baillie, M. G. L.; Bard, E.; Bayliss, A.; Beck, W.; Bertrand, C.; Blackwell, P. G.; Buck, C. E.; Burr, G. S.; Cutler, K. B.; et al. Intcal04 Terrestrial Radiocarbon Age Calibration, 0-26 Cal Kyr BP. Radiocarbon 2004, 46 (3), 1029-1058. https://doi.org/10.1017/S0033822200032999.

(38) Graven, H.; Allison, C.; Etheridge, D.; Hammer, S.; Keeling, R.; Levin, I.; Meijer, H.; Rubino, M.; Tans, P.; Trudinger, C.; et al. Compiled Records of Carbon Isotopes in Atmospheric CO2 for Historical Simulations in CMIP6. Geosci. Model Dev. 2017. http://dx.doi.org/10.5194/gmd-10-4405-2017. 
(39) Jeanneau, L.; Denis, M.; Pierson-Wickmann, A.-C.; Gruau, G.; Lambert, T.; Petitjean, P. Sources of Dissolved Organic Matter during Storm and Inter-Storm Conditions in a Lowland Headwater Catchment: Constraints from High-Frequency Molecular Data. Biogeosciences 2014, 12 (14), 4333-4343. https://doi.org/10.5194/bg-12-4333-2015.

(40) Nierop, K. G. J.; Preston, C. M.; Kaal, J. Thermally Assisted Hydrolysis and Methylation of Purified Tannins from Plants. Anal. Chem. 2005, 77 (17), 5604-5614. https://doi.org/10.1021/ac050564r.

(41) Grasset, L.; Rovira, P.; Amblès, A. TMAH-Preparative Thermochemolysis for the Characterization of Organic Matter in Densimetric Fractions of a Mediterranean Forest Soil. J. Anal. Appl. Pyrolysis 2009, $85 \quad$ (1), 435-441. https://doi.org/10.1016/j.jaap.2008.09.004.

(42) Frostegård, Å.; Tunlid, A.; Bååth, E. Phospholipid Fatty Acid Composition, Biomass, and Activity of Microbial Communities from Two Soil Types Experimentally Exposed to Different Heavy Metals. Appl Env. Microbiol 1993, 59 (11), 3605-3617.

(43) Rumpel, C.; Dignac, M.-F. Gas Chromatographic Analysis of Monosaccharides in a Forest Soil Profile: Analysis by Gas Chromatography after Trifluoroacetic Acid Hydrolysis and Reduction-Acetylation. Soil Biol. Biochem. 2006, 38 (6), 1478-1481. https://doi.org/10.1016/j.soilbio.2005.09.017.

(44) Goñi, M. A.; Hedges, J. I. Lignin Dimers: Structures, Distribution, and Potential Geochemical Applications. Geochim. Cosmochim. Acta 1992, 56 (11), 4025-4043. https://doi.org/10.1016/0016-7037(92)90014-A.

(45) Kögel, I. Estimation and Decomposition Pattern of the Lignin Component in Forest Humus Layers. Soil Biol. Biochem. 1986, 18 (6), 589-594. https://doi.org/10.1016/00380717(86)90080-5.

(46) R Core Team. A Language and Environment for Statistical Computing, R Foundation for Statistical Computing, Vienna, Austria (Http://R-Project.Org/). (http://Rproject.org/) 2019.

(47) Wickham, H. Ggplot2: Elegant Graphics for Data Analysis. Springer-Verlag New York 2016.

(48) Wickham, H.; François, R.; Henry, L.; Müller, K. Dplyr: A Grammar of Data Manipulation. R Package Version 0.8.0.1. Https://CRAN.R-Project.Org/Package=dplyr. 2019.

(49) Dinno, A. Dunn.Test: Dunn's Test of Multiple Comparisons Using Rank Sums. R Package Version 1.3.5. Https://CRAN.R-Project.Org/Package=dunn.Test. 2017.

(50) McKnight, D. M.; Boyer, E. W.; Westerhoff, P. K.; Doran, P. T.; Kulbe, T.; Andersen, D. T. Spectrofluorometric Characterization of Dissolved Organic Matter for Indication of Precursor Organic Material and Aromaticity. Limnol. Oceanogr. 2001, 46 (1), 38-48. https://doi.org/10.4319/1o.2001.46.1.0038.

(51) Hernes, P. J.; Benner, R. Photochemical and Microbial Degradation of Dissolved Lignin Phenols: Implications for the Fate of Terrigenous Dissolved Organic Matter in Marine $\begin{array}{lllllll}\text { Environments. J. Geophys. Res. Oceans 2003, } 108 & \text { (C9). }\end{array}$ https://doi.org/10.1029/2002JC001421.

(52) Spencer, R. G. M.; Stubbins, A.; Hernes, P. J.; Baker, A.; Mopper, K.; Aufdenkampe, A. K.; Dyda, R. Y.; Mwamba, V. L.; Mangangu, A. M.; Wabakanghanzi, J. N.; et al. Photochemical Degradation of Dissolved Organic Matter and Dissolved Lignin Phenols from the Congo River. J. Geophys. Res. Biogeosciences 2009, 114 (G3). https://doi.org/10.1029/2009JG000968.

(53) Laurion, I.; Mladenov, N. Dissolved Organic Matter Photolysis in Canadian Arctic Thaw Ponds. Environ. Res. Lett. 2013, 8 (3), 035026. https://doi.org/10.1088/17489326/8/3/035026. 
(54) Ward, C. P.; Cory, R. M. Complete and Partial Photo-Oxidation of Dissolved Organic Matter Draining Permafrost Soils. Environ. Sci. Technol. 2016, 50 (7), 3545-3553. https://doi.org/10.1021/acs.est.5b05354.

(55) Marschner, B.; Kalbitz, K. Controls of Bioavailability and Biodegradability of Dissolved Organic Matter in Soils. Geoderma 2003, 113 (3-4), 211-235. https://doi.org/10.1016/S0016-7061(02)00362-2.

(56) Lee, M.-H.; Osburn, C. L.; Shin, K.-H.; Hur, J. New Insight into the Applicability of Spectroscopic Indices for Dissolved Organic Matter (DOM) Source Discrimination in Aquatic Systems Affected by Biogeochemical Processes. Water Res. 2018, 147, 164176. https://doi.org/10.1016/j.watres.2018.09.048.

(57) Abbott, B. W.; Larouche, J. R.; Jones, J. B.; Bowden, W. B.; Balser, A. W. Elevated Dissolved Organic Carbon Biodegradability from Thawing and Collapsing Permafrost: Permafrost Carbon Biodegradability. J. Geophys. Res. Biogeosciences 2014, 119 (10), 2049-2063. https://doi.org/10.1002/2014JG002678.

(58) Estop-Aragonés, C.; Czimczik, C. I.; Heffernan, L.; Gibson, C.; Walker, J. C.; Xu, X.; Olefeldt, D. Respiration of Aged Soil Carbon during Fall in Permafrost Peatlands Enhanced by Active Layer Deepening Following Wildfire but Limited Following Thermokarst. Environ. Res. Lett. 2018, 13 (8), 085002. https://doi.org/10.1088/17489326/aad5f0.

(59) Vonk, J.; Tank, S.; Mann, P.; Spencer, R.; Treat, C.; Striegl, R.; Abbott, B.; Wickland, K. Biodegradability of Dissolved Organic Carbon in Permafrost Soils and Aquatic Systems: A Meta-Analysis. Biogeosciences BG 2015, 12, 6915-6930.

(60) Estop-Aragonés, C.; Cooper, M. D. A.; Fisher, J. P.; Thierry, A.; Garnett, M. H.; Charman, D. J.; Murton, J. B.; Phoenix, G. K.; Treharne, R.; Sanderson, N. K.; et al. Limited Release of Previously-Frozen C and Increased New Peat Formation after Thaw in Permafrost Peatlands. Soil Biol. Biochem. 2018, 118, 115-129. https://doi.org/10.1016/j.soilbio.2017.12.010.

(61) Spencer, R. G. M.; Mann, P. J.; Dittmar, T.; Eglinton, T. I.; McIntyre, C.; Holmes, R. M.; Zimov, N.; Stubbins, A. Detecting the Signature of Permafrost Thaw in Arctic Rivers. J. Geophys. Res. Oceans 2016, 2830-2835. https://doi.org/10.1002/2015GL063498@10.1002/(ISSN)2169-9291.ARCTICJOINT.

(62) Mann, P. J.; Eglinton, T. I.; McIntyre, C. P.; Zimov, N.; Davydova, A.; Vonk, J. E.; Holmes, R. M.; Spencer, R. G. M. Utilization of Ancient Permafrost Carbon in Headwaters of Arctic Fluvial Networks. Nat. Commun. 2015, 6, 7856. https://doi.org/10.1038/ncomms8856.

(63) Ewing, S. A.; O’Donnell, J. A.; Aiken, G. R.; Butler, K.; Butman, D.; Windham-Myers, L.; Kanevskiy, M. Z. Long-Term Anoxia and Release of Ancient, Labile Carbon upon Thaw of Pleistocene Permafrost. Geophys. Res. Lett. 2015, 42 (24), 10,730-10,738. https://doi.org/10.1002/2015GL066296.

(64) Hansen, A. M.; Kraus, T. E. C.; Pellerin, B. A.; Fleck, J. A.; Downing, B. D.; Bergamaschi, B. A. Optical Properties of Dissolved Organic Matter (DOM): Effects of Biological and Photolytic Degradation. Limnol. Oceanogr. 2016, 61 (3), 1015-1032. https://doi.org/10.1002/lno.10270.

(65) Shirokova, L. S.; Chupakov, A. V.; Zabelina, S. A.; Neverova, N. V.; Payandi-Rolland, D.; Causserand, C.; Karlsson, J.; Pokrovsky, O. S. Humic Surface Waters of Frozen Peat Bogs (Permafrost Zone) Are Highly Resistant to Bio- and Photodegradation. Biogeosciences 2019, 16 (12), 2511-2526. https://doi.org/10.5194/bg-16-2511-2019. 
640 Table 1. General water quality ( $\mathrm{pH}$, conductivity), DOC concentrations, optical properties (FI and SUVA); and $\delta^{13} \mathrm{C}-\mathrm{signature}$ of DOM in 641 porewater of thermokarst bogs and surface water of thermokarst lakes. sd: Standard deviation.

\begin{tabular}{llllllll} 
& $\mathrm{n}$ & $\mathrm{pH}$ & Cond. $\left(\mu \mathrm{S} \mathrm{cm}^{-1}\right)$ & $\mathrm{DOC}\left(\mathrm{mg} \mathrm{L}^{-1}\right)$ & $\mathrm{FI}$ & $\mathrm{SUVA}\left(\mathrm{L} \mathrm{mgC} \mathrm{m}^{-1}\right)$ & $\delta^{13} \mathrm{C}-\mathrm{DOC}(\%)$ \\
\hline Small bogs & 10 & $4.5 \pm 0.2$ & $69 \pm 40$ & $44.1 \pm 10.1$ & $1.35 \pm 0.06$ & $5.36 \pm 0.60$ & $-27.7 \pm 0.3$ \\
Large bogs & 12 & $5.0 \pm 1.0$ & $82 \pm 38$ & $16.7 \pm 1.2$ & $1.51 \pm 0.06$ & $4.81 \pm 0.34$ & $-29.0 \pm 0.8$ \\
Fens & 8 & $5.7 \pm 1.2$ & $47 \pm 48$ & $11.0 \pm 2.4$ & $1.55 \pm 0.06$ & $4.83 \pm 0.63$ & $-28.5 \pm 1.1$ \\
Therm. Lakes & 12 & $4.6 \pm 0.9$ & $40 \pm 36$ & $14.0 \pm 4.2$ & $1.5 \pm 0.05$ & $4.88 \pm 0.48$ & $-28.8 \pm 1.0$ \\
Mineral Bog & 9 & $5.4 \pm 0.6$ & $44 \pm 24$ & $12.9 \pm 2.3$ & $1.64 \pm 0.05$ & $4.28 \pm 0.80$ & $-29.4 \pm 0.3$
\end{tabular}


645 Table 2. DOM molecular analysis in porewater of thermokarst bogs and lakes (mean \pm sd). SA: small acids, CAR: carbohydrates, FA: fatty acids, 646 PHE: phenolic compounds, LMWFA: low molecular weight fatty acids, pcVEG: percentage of vegetation, C/V: ratio of cinnamyl to vanillyl acids,

$647 \mathrm{~S} / \mathrm{V}$ : ratio of syringyl to vanillyl acids, $(\mathrm{Al} / \mathrm{Ac})_{\mathrm{V}}$ : ratio of aldehyde to acid moieties for vanillyl, (A1/Ac) $)_{\mathrm{S}}$ aldehyde to acid moieties for syringyl.

\begin{tabular}{|c|c|c|c|c|c|c|c|c|}
\hline & CAR & $\mathrm{FA}$ & LMWFA & $\mathrm{pcVEG}$ & $\mathrm{C} / \mathrm{V}$ & $\mathrm{S} / \mathrm{V}$ & $(\mathrm{Al} / \mathrm{Ac}) \mathrm{v}$ & $(\mathrm{Al} / \mathrm{Ac}) \mathrm{s}$ \\
\hline SB & $31.2 \pm 0.4$ & $3.9 \pm 0.8$ & $47.6 \pm 5.5$ & $86.3 \pm 8.2$ & $78.0 \pm 5.0$ & $0.10 \pm 0.0$ & $0.38 \pm 0.1$ & $0.10 \pm 0.0$ \\
\hline LB & $20.0 \pm 4.9$ & $6.1 \pm 3.0$ & $39.5 \pm 6.0$ & $65.8 \pm 21.3$ & $70.6 \pm 6.7$ & $0.50 \pm 0.2$ & $0.43 \pm 0.1$ & $0.21 \pm 0.1$ \\
\hline MB & $23.6 \pm 4.6$ & $3.3 \pm 0.4$ & $45.1 \pm 3.2$ & $83.5 \pm 11.0$ & $69.5 \pm 6.6$ & $0.32 \pm 0.1$ & $0.45 \pm 0.0$ & $0.13 \pm 0.0$ \\
\hline Lake & $23.7 \pm 5.7$ & $8.0 \pm 0.4$ & $56.0 \pm 4.2$ & $96.5 \pm 0.1$ & $81.5 \pm 0.7$ & $0.13 \pm 0.0$ & $0.29 \pm 0.1$ & $0.08 \pm 0.0$ \\
\hline
\end{tabular}

649 
651 Table 3. Relationships between radiocarbon content of DOM and SUVA index for this study

652 and reported results from the literature.

\begin{tabular}{|c|c|c|c|}
\hline Study & Scale & Geological Context & SUVA $=\mathbf{a F}^{\mathbf{1 4}} \mathbf{C}+\mathbf{b}$ \\
\hline This study & Thermokarst bogs pore water profile & Holocene peatlands & $\begin{array}{l}y=-4.78 x+9.53 \\
r^{2}=0.55, n=21, p<0.001\end{array}$ \\
\hline Mann et al., 2015 & Thaw water, streams & Yedoma & $\begin{array}{l}\mathrm{y}=2.23 \mathrm{x}+1.29 \\
\mathrm{r}^{2}=0.78, \mathrm{n}=23, \mathrm{p}<0.0001\end{array}$ \\
\hline Barnes et al., 2018 & Yeniseï River & Yenissei watershed & $\begin{array}{l}\mathrm{y}=5.90 \mathrm{x}-3.14 \\
\mathrm{r}^{2}=0.25, \mathrm{n}=45, \mathrm{p}<0.001\end{array}$ \\
\hline Wang et al., 2018 & Pond waters & High Canadian Arctic & $\begin{array}{l}y=8.17 x-3.36 \\
r^{2}=0.38, n=15, p<0.05\end{array}$ \\
\hline
\end{tabular}

653

654 
655

656

657

658

659

660

661

662

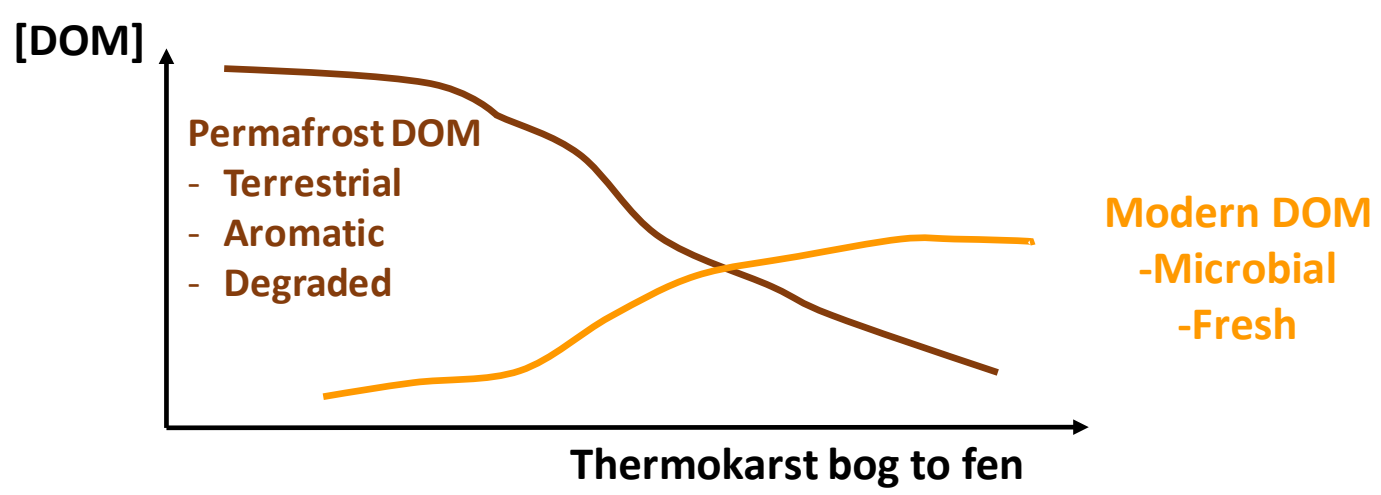

$\mathrm{F}^{14} \mathrm{C}$

FI

LMWFA

SUVA

$\delta^{13} \mathrm{C}-\mathrm{DOC}$

663

(Al.Ac)V, C/V

664 Graphical abstract.

665

666

667

668

669 


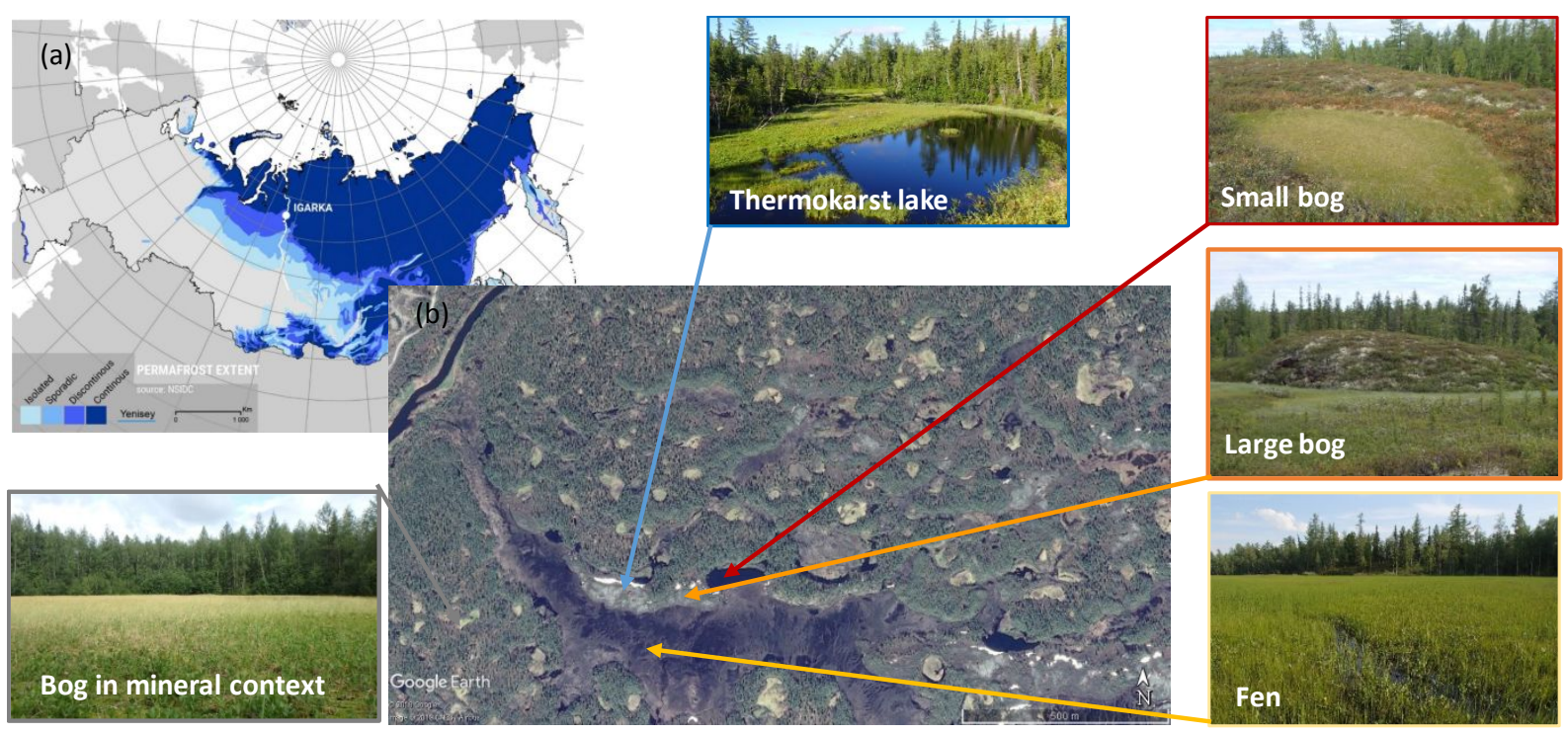

674 Figure 1. (a) Location of Igarka and permafrost status in the Republic of Russia. (b) Sampling 675 area, with location of sampling points. Pictures are representative of sampling locations. Data from IPA (International Permafrost Association) and Google Earth. 


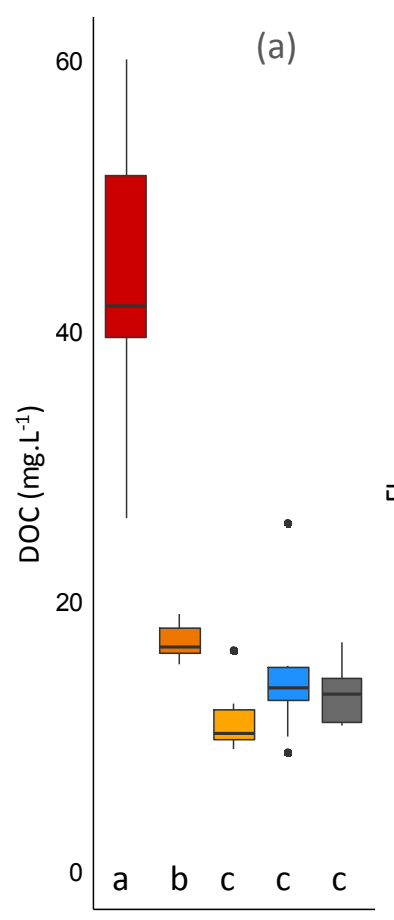

(b)

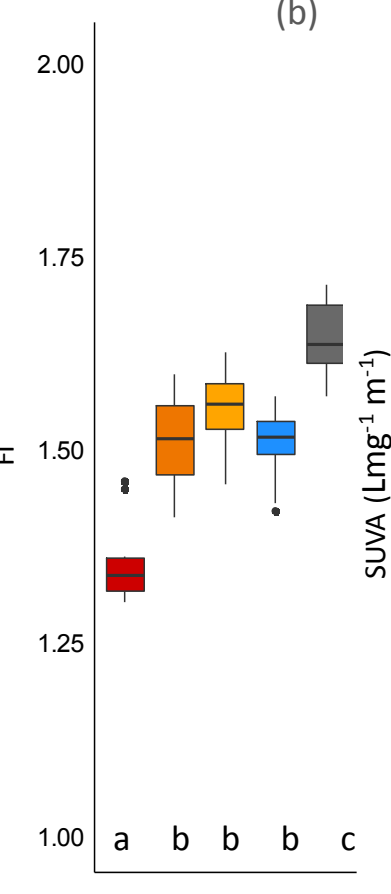

(c)

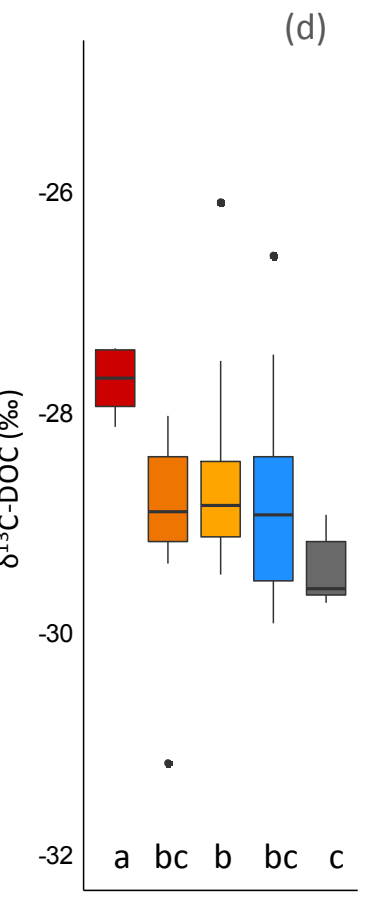

므 $\mathrm{SB}$ 自

688 Figure 2. (a) DOC concentration, (b) Fluorescence Index (FI), (c) Specific UV Absorbance (SUVA) and (d) $\delta^{13} \mathrm{C}$ of DOM of the different sample types. The black line is the median. The lower and upper levels of the box represent the 25 and $75 \%$ quartile, respectively. The lower whisker is smallest observation greater than or equal to lower hinge $-1.5 *$ IQR (inter-quartile range), the upper whisker, the upper whisker is the largest observation less than or equal to upper hinge $+1.5 * \mathrm{IQR} . \mathrm{SB}=$ small bogs, $\mathrm{LB}$ $=$ large bogs, lake $=$ thermokarst lake, $\mathrm{MB}=$ thermokarst bog developed in mineral context. Letters represent significantly different groups (Kruskall Wallis and Dunn's post hoc multiple test $(\mathrm{p}>0.05))$. 

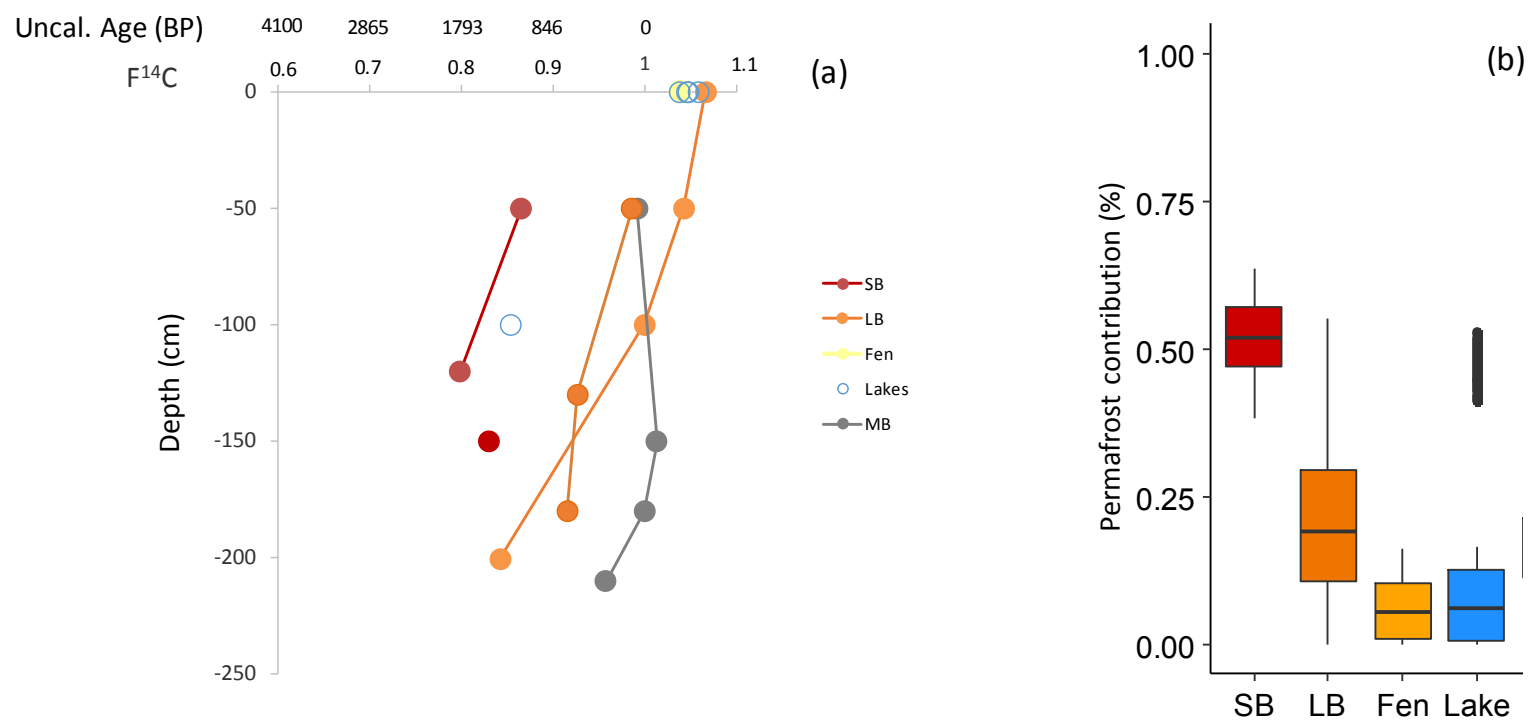

703

704

705

706

707

708

709

710

711

712

713

714

Figure 3. (a) Profiles of radiocarbon content of selected samples of DOM in thermokarst bogs profiles, porewater surface, sediment porewater of lake and surface water of lakes. (b) Proportion of permafrost to DOM. The distribution corresponds to calculation with atmospheric signature ranging from 1980 to 2015 (sampling date). $\mathrm{SB}=$ small bogs, $\mathrm{LB}=$ large bogs, Lake = thermokarst lake, $\mathrm{MB}=$ thermokarst bog developed in mineral context. 

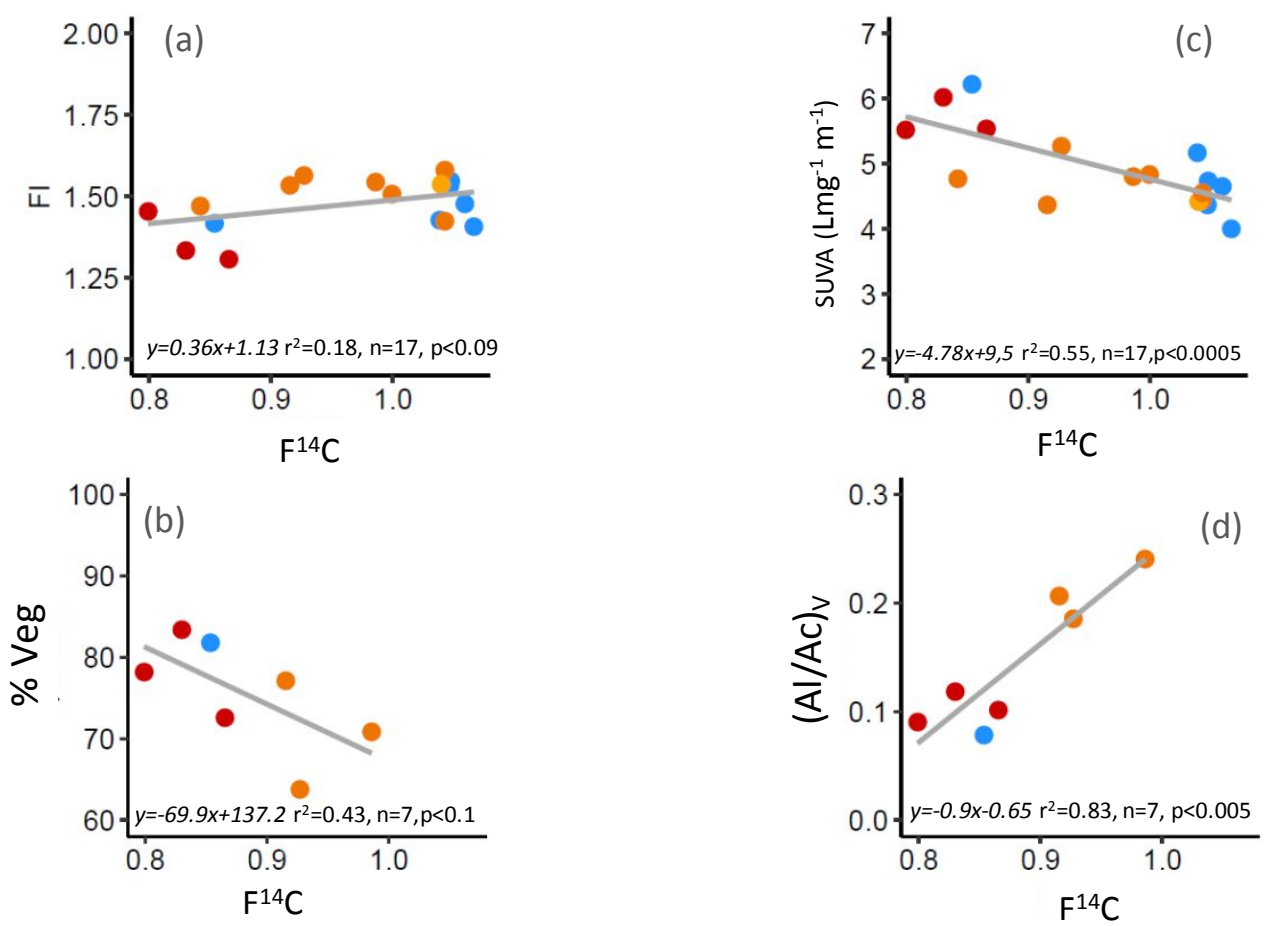

717 - SB • LB • Fen • Lake

719 Figure 4. Relationship between radiocarbon content of DOM with (a) FI (Fluorescence Index), (b), SUVA (Specific UV Absorbance), (c) percentage of vegetation origin of DOM, (d) $(\mathrm{Al} / \mathrm{Ac})_{\mathrm{V}}$ : ratio of aldehyde to acid moieties for vanillyl. $\mathrm{SB}=$ small bogs, $\mathrm{LB}=$ large bogs, Lake $=$ thermokarst lake. 


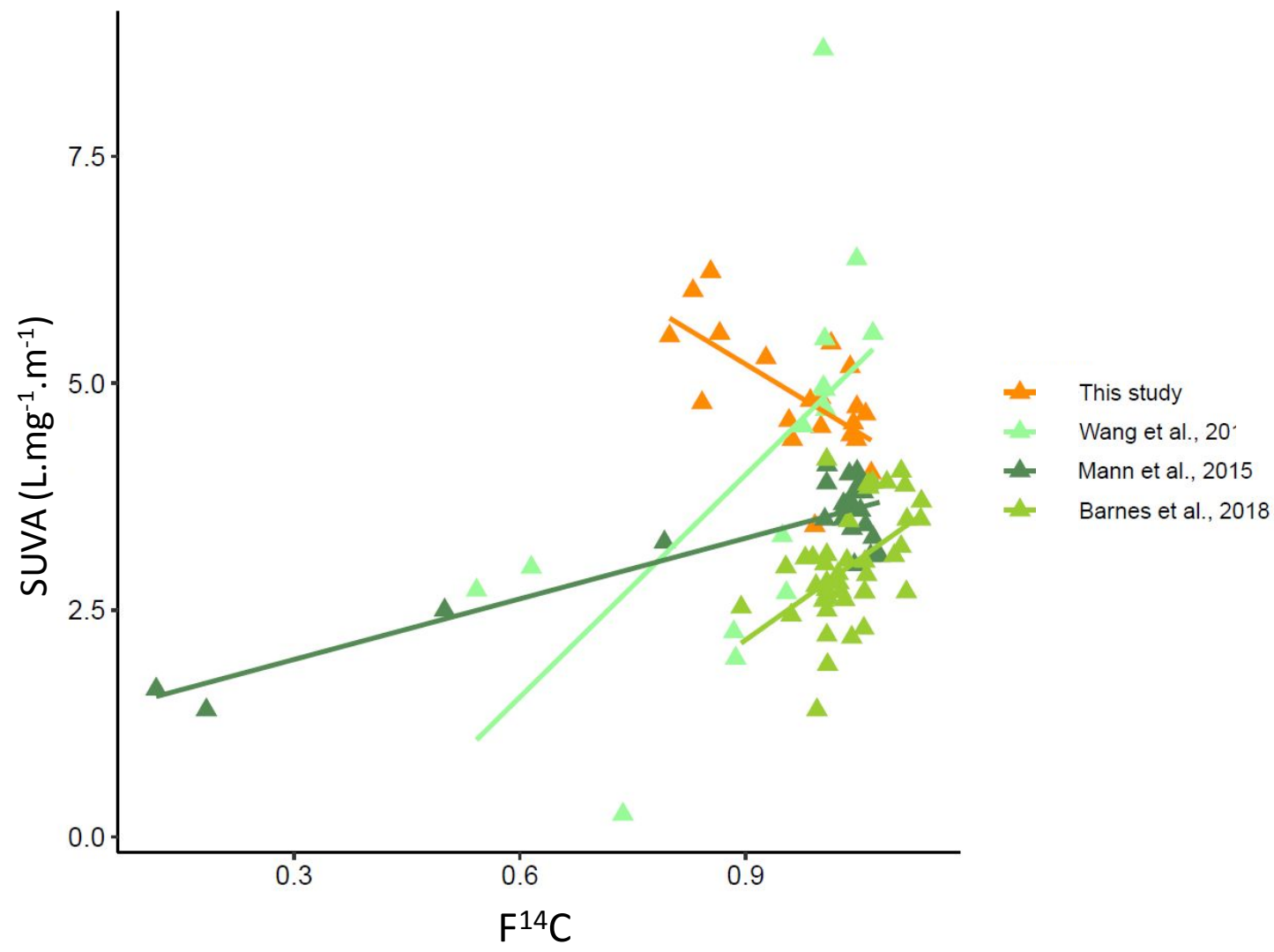

726

727 Figure 5: Relationship radiocarbon content of DOM and SUVA in different geological contexts and at different scales. (Wang et al., 2018 : High Arctic ponds, Mann et al., 2015 : Streams and thaw water in Yedoma Context, Barnes et al., 2018 : Yenisei watershed). 